\title{
Article \\ Bridging Green Gaps: The Buying Intention of Energy Efficient Home Appliances and Moderation of Green Self-Identity
}

\author{
Ya Li $^{1,2}$, Abu Bakkar Siddik ${ }^{3, *}$, Mohammad Masukujjaman ${ }^{4}\left(\mathbb{D}\right.$ and Xiujian Wei ${ }^{1}$ \\ 1 School of Economics and Finance, Xi'an Jiaotong University, Xi'an 710049, China; wstliya@126.com (Y.L.); \\ weixj@mail.xjtu.edu.cn (X.W.) \\ 2 Medical Management Service Center of Shandong Health Commission (International Health Exchange \\ Center of Shandong Province), Lixia District, Jinan 250014, China \\ 3 School of Economics and Management, Shaanxi University of Science and Technology (SUST), \\ Weiyang District, $\mathrm{Xi}^{\prime}$ an 710021, China \\ 4 Department of Business Administration, Northern University Bangladesh, Banani C/A, \\ Dhaka 1213, Bangladesh; masukujjaman@nub.ac.bd \\ * Correspondence: 1s190309@sust.edu.cn; Tel.: +86-156-8601-2117
}

check for updates

Citation: Li, Y.; Siddik, A.B.;

Masukujjaman, M.; Wei, X. Bridging Green Gaps: The Buying Intention of Energy Efficient Home Appliances and Moderation of Green SelfIdentity. Appl. Sci. 2021, 11, 9878. https://doi.org/10.3390/app11219878

Academic Editor: Pietro Picuno

Received: 17 September 2021

Accepted: 19 October 2021

Published: 22 October 202

Publisher's Note: MDPI stays neutral with regard to jurisdictional claims in published maps and institutional affiliations.

Copyright: (c) 2021 by the authors. Licensee MDPI, Basel, Switzerland. This article is an open access article distributed under the terms and conditions of the Creative Commons Attribution (CC BY) license (https:// creativecommons.org/licenses/by/ $4.0 /)$.

\begin{abstract}
This study investigates the factors influencing the buying intention of energy-efficient home appliances in Bangladesh. It also develops a conceptual framework that integrates additional constructs with the theory of planned behavior (TPB) and borrows questions from past literature. Employing a convenience sampling technique, a total of 365 completed structured questionnaires were gathered from various super shops in Dhaka, Bangladesh. The structural equation modeling (SEM) technique was thereafter used to analyze the data with the AMOS 21. The study established that environmental knowledge, attitude, subjective norms, and perceived behavioral control significantly affected the consumers' buying intention of energy-efficient home appliances (EEHA). The result revealed a significant relationship between environmental concern, environmental knowledge, subjective norms, eco-labeling, and attitude towards buying. It also confirmed that the green self-identity moderates the existent relationship between the attitude and buying intention of energy-efficient home appliances, while environmental knowledge does not. The research advances numerous policy suggestions to managers or marketers, as well as future research directions.
\end{abstract}

Keywords: buying intention; energy-efficient home appliances; green self-identity; theory of planned behavior

\section{Introduction}

A household sector plays a significant role in energy conservation and environmental sustainability in using energy-saving goods [1]. Smaller energy demand and improved efficiency are widely recognized as the most optimistic, fast, economical, and secure alternative to alleviating environmental deterioration and climate change [2,3]. Globally, policymakers have emphasized the need for individuals to take responsibility for their immediate environment. These include recycling, use of green label products, and reduction in power usage [4]. Products that swiftly dissipate energy are considered important in achieving efficiency and reducing carbon emissions [5-7]. However, energy saves in the residential sector are dependent on users' technological and habitual behavior. Technological choices include consumers' preference for energy-efficient or traditional equipment, while habitual acts include their practices of turning off appliances when not in use [8]. However, energy-efficient appliances (EEA) offer more energy efficiency and sustainability than habitual corrections. Also, they do not require continuous customer efforts and is a one-time expenditure [9].

Energy-efficient appliances use less electricity while maintaining the same performance, convenience, and comfort [10]. Concerns about rising emissions have resulted in 
investments in energy-efficient \& conservation (EEC) projects [11]. However, it is worth noting that the terms "energy efficiency" and "energy conservation" have fundamentally distinct meanings. Energy efficiency entails the minimization of direct energy use through advancements in technology [12], while energy conservation involves the use of technology or modification of human behavior towards the conservation of energy [13]. Consumer behavior must be altered for the successful adoption of EEA, but not for energy conservation [14].

Intensive research has been conducted on the buying behavior of energy-efficient appliances in advanced economies like the UK, Netherlands, Australia, USA, Germany, and Switzerland [4,15-19], and emerging economies like Malaysia, China, Vietnam, India, and South Korea [5,20-23]. From the understanding of the researcher, no similar study has been conducted from the Bangladeshi perspective. Since each country is unique in its socio-economic conditions and resource availability, decision-making on technology choices varies. As a result, an investigation into the barriers and reasons for the lack of the diffusion of energy-saving technology from the Bangladeshi perspective is necessary. As Bangladesh is characterized by a progressive GDP and per capita income growth, it is important to determine what people think of modern and energy-efficient home appliances from a newly developing economic perspective.

The TPB has been utilized in many pro-environmental research areas, including lowconsumption appliances [1,5,24-27], and despite its widespread acceptance, the model has been criticized. The major complaint is stemmed on the need for more variables to improve its predictive and explanatory power $[6,28,29]$. Some researchers claimed that the TPB paradigm fails to address a sufficient variety of intentions [30,31], and as a result, additional factors can be included in the TPB if they provide a significant understanding of the behavior [32,33]. Therefore, to improve the explanatory power of the TPB, researchers have suggested the addition of new variables that are meaningful as much as to theoretically influence intentions [34-36]. In addition, attitude-intention, also regarded as the green gap, is one of the inherited problems of the TPB model. Researchers [9,37-39] studied the attitude-intention gaps and suggested constructs such as ethical consumption behavior, environmental knowledge, and environmental concern, but ignored the construct of green emotion or green responsibility (green self-identity) narrowing the gaps. Thus, there is a critical need to explore these factors empirically.

Previous studies on environmental psychology examined how self-identities predict behavior. For instance, the energy-saving self-identity predicts energy-saving intention [40], while the recycling self-identity predicts recycling behaviors [41]. The same cannot be said for other pro-environmental activities. A broad spectrum of pro-environmental attitudes, intentions, and behaviors are related to a more general environmental self-identity $[42,43]$. An individual's general green identity influences their pro-environmental action, and as a result, addressing this overall environmental self-identity becomes more useful to spur pro-environmental actions. Qasim et al. [44] used environmental self-identity to moderate the relationship between consumption value and behavioral intent, while Neves and Oliveira [45] used it to moderate the relationship between co-benefits, labeling, operations and maintenance, and savings. However, to the researcher's knowledge, none of these factors assessed the green self-identity as a moderator between attitude-intention to bridge the TPB's inherited gaps. Hence, the scope of this study lies in the identification of the impact of green self-identity on the consumers' buying intention of products like energyefficient home appliances.

In previous studies [46,47], environmental knowledge was considered as one of the most direct indicators of environmental behavior. However, much research has highlighted a minimal direct association between environmental knowledge and environmental performance [48]. According to Kollmuss and Agyeman [49], the direct relationship existent between green awareness and PEB is still unknown. Since a contradictory result exists in the past literature, there is a need to retest the variable for validation from a developing country's perspective. Likewise, Kim et al. [50] observed a coherent SN-Attitude 
relationship but not with the BI, while Anssi Tarkiainen Sanna Sundqvist [51] observed a relationship with intention but not with Attitude. However, there is still an unexplored question of whether subjective norms simultaneously affect attitude and buying intention or not.

Therefore, to adequately address the gaps above in the literature, the present study investigates the determinants of Bangladeshis' buying intention of the EEHA. This paper adds to the body of knowledge twofold; a new context and new variables. The present study would like to see the necessary factors in the purchase intention of Bangladeshi shoppers, which will broaden the view of EEHA buying in a developing country context. Regarding the new variables, this study adopts the TPB model while incorporating additional constructs such as green self-identity, environmental concern, environmental knowledge, and eco-labeling. The green self-identity and environmental knowledge and green self-identity were proposed as moderating variables between attitude and buying intention to narrow down the prevailing green gap and provide a comprehensive understanding of the problem.

The remainder of this article is structured as follows: Section 2 offers a review of the relevant literature and formulates hypotheses. Section 3 details the methodology and data collection procedures employed in this investigation. Section 4 discusses the analysis of data to verify the validity and reliability of the employed method and assesses the predicted results produced. Section 5 presents the results and implications of the study. Section 6 addresses the limitations and provides suggestions for future study.

\section{Literature Review and Hypothesis Development}

The study adopted the theory of planned behavior as the underpinning theory and also added some context-wise factors (environmental concern, environmental knowledge, eco-labeling, and green self-identity) based on the massive literature review (Table 1) in the proposed model to fulfill objectives, as can be seen in Figure 1.

\subsection{Theory of Planned Behavior}

The theory of planned behavior (TPB) is a common theory employed in the prediction of human behavior that can be easily controlled when compared to other cognitive elements [32]. Owing to its accuracy, it remains one of the most important social psychology theories for the prediction of the conduct of individuals [32] and was first developed as an extension of the reasoned theory of action (TRA). According to the TRA, the customer's use of a product is contingent on their intention to use it, which is created in accordance with social norms [52]. Since the TPB provides a framework for studying behavioral predictors, individual behavior is determined by behavioral intents and influenced by attitudes toward behavior, subjective norms, and perceived behavioral control $[53,54]$. The TPB states that: "The more the behavioral intentions, the greater the probability of exhibiting a specific behavior.

\subsubsection{Attitude and Buying Intention}

Attitude refers to a predisposition or proclivity toward a notion, person, or situation. It denotes a broad assessment of an individual's behavior that results in a positive end. The TPB asserts that attitude determines intention, which in turn defines human behavior. As an instance, Yadav and Pathak [55] examined the factors influencing green purchasing behavior and discovered that attitude has a favorable effect on buying intentions. Also, numerous studies have reported that attitude substantially influences the purchase intention of consumers with regards to energy-saving equipment $[5,56,57]$. Owing to the favorable relationship existent between attitude and intentions towards the purchase of energy-efficient appliances, the following hypothesis is proposed:

Hypothesis 1. Attitude is significantly and positively related to the intention of residents to purchase EEHA. 


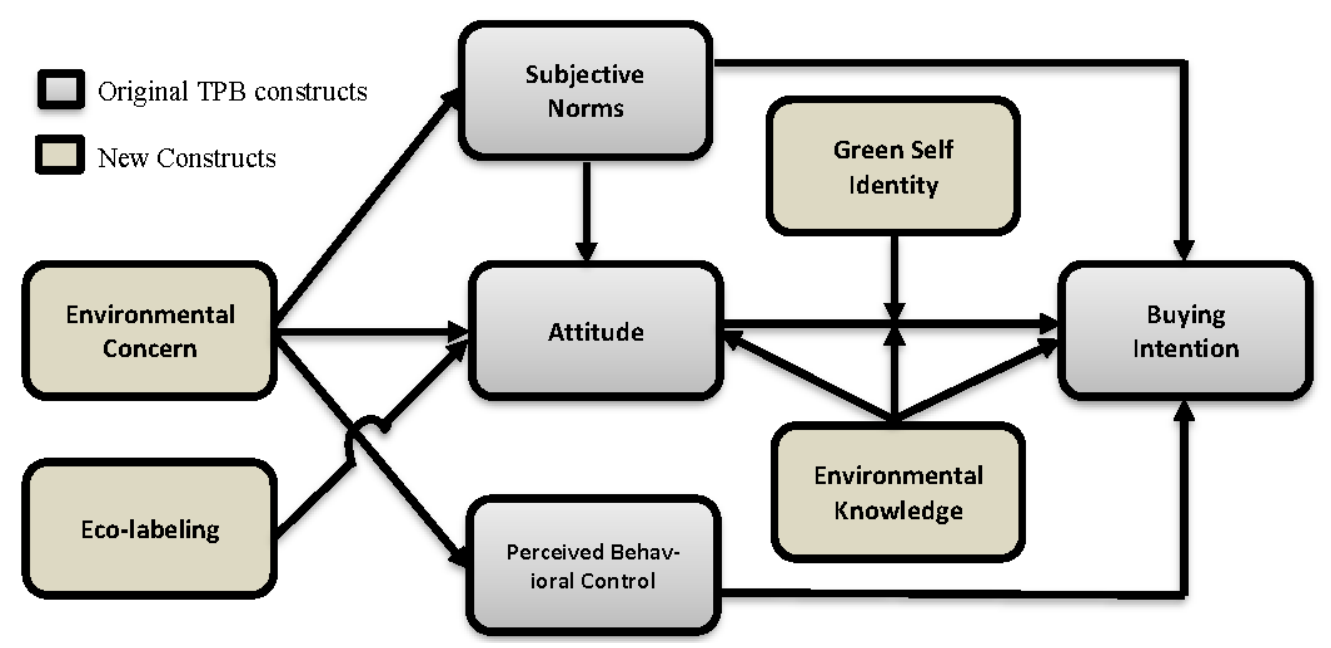

Figure 1. Conceptual Framework [Source: Authors compilation].

\subsubsection{Subjective Norms}

Subjective norm refers to the perceived social consequences of "performing" or "refraining from performing" [32]. Individuals frequently imitate others and adhere to various social norms. These practices are a society's 'guideline' norms or behavioral desires that govern what is considered acceptable and desirable [57]. Earlier research established the perceived norm as a strong predictor of plans to acquire energy-efficient appliances [58,59]. The latest evidence in South Korea, depending on survey questions to evaluate Korean customers' buying intention toward EEAs, discovered that SN had a favorable effect on EEHA [9]. Furthermore, Wang et al. [60] noted that this impact also applies to EEA purchase intentions. Additional research from around Asia [61,62] has backed up these outcomes. Furthermore, Ali et al. [1] discovered a non-significant connection between SN and purchase intent of energy-saving items in the case of Pakistani consumers' inclination to buy energy-saving products. Nevertheless, Tan et al. [5] identified that SN does not have a substantially positive connection with EEA buying intention, and the absence of a link implies that customers are not easily affected by other people's judgments. As a result, the following hypotheses are proposed:

Hypothesis 2. Subjective norm is significantly and positively related to the attitude of residents towards the purchase of EEHA.

Hypothesis 3. Subjective norm is significantly and positively related to the intention of residents to purchase EEHA.

\subsubsection{Perceived Behavioral Control (PBC)}

$\mathrm{PBC}$ is a term that relates to the perceived ease or difficulty of engaging in an activity. It is formed by external and internal factors that either encourage or discourage a person from indulging in the action. As an instance, when customers adopt a new product, they establish the effort and resource needs [63]. Convenience factors such as price incentives, appliance availability, and the trustworthiness of energy efficiency labels all play a role in the context of EEHA [64]. Wang et al. [6] evaluated the behavioral intention for electric vehicles by quantifying the PBC in relation to price and availability. The PBC was observed to have a favorable influence on the adoption intentions in this study. The PBC was described by Wang et al. [65] as the perceived discomfort and financial benefits related to an energy conservation activity. Wang et al. [6] also discovered a significant influence of the $\mathrm{PBC}$ on energy-saving behavior, resulting in the postulation of the following hypothesis:

Hypothesis 4. The PBC is significantly and positively related to the intention of residents to purchase EEHA. 
Table 1. The Buying Intention of Energy-Efficient Appliances in Asian Countries.

\begin{tabular}{|c|c|c|c|}
\hline Country & Authors & Sample/Analysis Method & Constructs Found Significant \\
\hline Pakistan & {$[66]$} & 673/PLS-SEM/MGA & $\begin{array}{l}\text { Warm glow benefits, utilitarian environmental benefits, perceived } \\
\text { behavioral control, normative beliefs, eco-literacy, attitude, and } \\
\text { subjective norm }\end{array}$ \\
\hline Pakistan & [1] & 289/PLS SEM & $\begin{array}{l}\text { Attitude, policy information campaigns, past purchase experience, } \\
\text { and } P B C\end{array}$ \\
\hline China & {$[67]$} & $\begin{array}{l}1472 / \text { Logistic } \\
\text { regression/SPSS }\end{array}$ & Incomes, household size, and dwelling areas \\
\hline China & [24] & 305/PLS SEM & $\begin{array}{l}\text { Environmental concern, subjective norm, attitude, environmental } \\
\text { knowledge, and PBC }\end{array}$ \\
\hline China & {$[68]$} & 477/SEM/AMOS & $\begin{array}{l}\text { Personal norm, } \mathrm{PBC} \text {, awareness of consequences, attitude, ascription } \\
\text { of responsibility, and subjective norm. }\end{array}$ \\
\hline India & [69] & $\begin{array}{l}\text { 300/Multiple } \\
\text { Regression/SPSS }\end{array}$ & $\begin{array}{l}\text { Perceived product risk, skepticism towards label claims, price } \\
\text { sensitivity, perceived personal inconvenience, and subjective norms }\end{array}$ \\
\hline South-Korea & [70] & 304/Logistic regression/SPSS & Price and eco-label \\
\hline Pakistan & [1] & 396/PLS SEM & Innovativeness, PBC, attitude, insecurity, discomfort, and optimism, \\
\hline Malaysia & {$[5]$} & 210/PLS SEM & Attitude, PBC, and moral norms \\
\hline China & [57] & 253/SEM/AMOS & Attitude, PBC, subjective norms, and residual effect \\
\hline South-Korea & [9] & 1050/SEM/AMOS & $\begin{array}{l}\text { Trust, social responsibility, environmental knowledge, and perceived } \\
\text { cost. }\end{array}$ \\
\hline
\end{tabular}

Source: Authors compilation. Note: PLS-SEM = Partial Least Square Structural Equation Modeling, MGA = Multi-group Analysis, SPSS $=$ Statistical Packages for Social Science, AMOS = Analysis of a Moment Structures.

\subsubsection{Environmental Concern}

Environmental concern, one of the vital cognitive constructs in the prediction of green products [71], is described by Crosby et al. as "a strong environmental protection attitude" [72]. According to Yadav \& Pathak [55], a favorable attitude toward such green things has a beneficial effect on the environment. In an empirical examination of Indian customers, Jaiswal and Kant [71] discovered that environmental concerns were positively connected with attitudes towards green products [71]. In addition, some earlier studies also included this cognitive element in the TPB framework. Chen and Tung merged environmental concern (EC) into an extended TPB framework and discovered that a better EC had a better impact on the attitude, subjective (SN), and PBC of green hotel visitors [73]. Similar results were also obtained by the study conducted by Paul et al. [74], which concluded that EC was favorably linked to the green items and TPB variables. In view of the above discourse, this study coupled the EC with TPB and subsequently advanced the following assumptions:

Hypothesis 5. Environmental concern has a significant and positive relation to subjective norms.

Hypothesis 6. Environmental concern has a significant and positive relation to attitudes toward EEHA.

Hypothesis 7. Environmental concern has a significant and positive relation to perceived behavioral control.

\subsubsection{Environmental Knowledge}

Consumer knowledge is an important aspect of consumer behavior [75], and its comprehension can, in particular, aid companies in an understanding of the information search and data processing behavior of customers. Environmental knowledge (EK) refers to an individual's environmental expertise, knowledge, and other related problems [76]. Persons 
with specific ecological knowledge tend to have a positive attitude to ecological behavior and are strongly prepared to take action. Flamm [77] discovered that households having a greater ecological awareness are more likely to purchase energy-efficient vehicles and that research has revealed that ecological knowledge has a favorable impact on customer attitude with respect to green products $[47,78,79]$. Latif et al. [80] demonstrated that EK influences the attitude of residents towards green products, which in turn affects their intention to purchase green items $[6,81]$. The following hypotheses are hereby presented:

Hypothesis 8. Environmental knowledge is significantly and positively related to the attitude of residents towards the purchase of EEHA.

Hypothesis 9. Environmental knowledge is significantly and positively related to the intention of residents to buy EEHA.

\subsubsection{Eco-Labeling}

Eco-labels are regarded as crucial green marketing tools. As eco-labels are informative instruments for the use, disposal, consumption, and manufacture of items, marketers can seamlessly transmit the ecological benefits of products via eco-labeling [82]. The multidimensional side of eco-labels employed by Prieto-Sandoval et al. [83] encompasses the empirical, geographical, and sectorial views. Since consumers are now very interested in their environment, the possibilities of purchasing eco-labeled products are relatively high. In addition, customer preferences tend to increase when information about energy usage is adequately communicated via well-designed energy labels $[68,84,85]$. Cho [86] emphasizes the significant impact of ecological and sustainability labeling on a company's attitude. Simon [87] also suggested that environmentally friendly items adhere to the attitude of emerging environmental values. The following theory is subsequently proposed:

Hypothesis 10. Subjective norms are significantly and positively related to the attitude of residents toward the purchase of EEHA.

\subsubsection{Moderation of Ethical Self-Identity and Environmental Knowledge}

Self-identity is the collection of roles portrayed by a person, resulting in a consistent action for self-concept [88]. It is a label used by an individual to bear or identify a particular behavior [89]. Thus, environmental self-identity is described as "an individual's opinion of themselves as an environmentally friendly person" [90]. However, it is important to distinguish between environmental self-identification and environmental identity [91].

Recent research has recognized the mediating effect of consumers' self-identity on the relationship between customer motivation/value and organic food purchase intention [92,93]. To this effect, Van der Werff, Steg, and Keizer [90] revealed that the link between the ecological values, pro-environmental intentions, and behavior of consumers influences green identity. In other words, Environmental knowledge moderates the impact of attitude on the procurement decision of organic foods [94], as a higher level of consumer knowledge results in more comfortable behavior [95]. This, in turn, reduces the impact on the behavior of consumers towards external pressures. In line with the preceding discussion, the following proposition is therefore suggested:

Hypothesis 11. Green self-identity positively moderates the relationship between the attitude and purchase intention of EEHA.

Hypothesis 12. Environmental knowledge positively moderates the relationship between the attitude and purchase intention of EEHA. 


\section{Materials and Methods}

This is exploratory research based on empirical data (Figure 2). The study utilized original data from a survey of customers to ascertain the factors impacting their green purchasing decisions. It employed a cross-sectional survey design, implying that data was gathered to evaluate the inference of the population at a particular point in time.

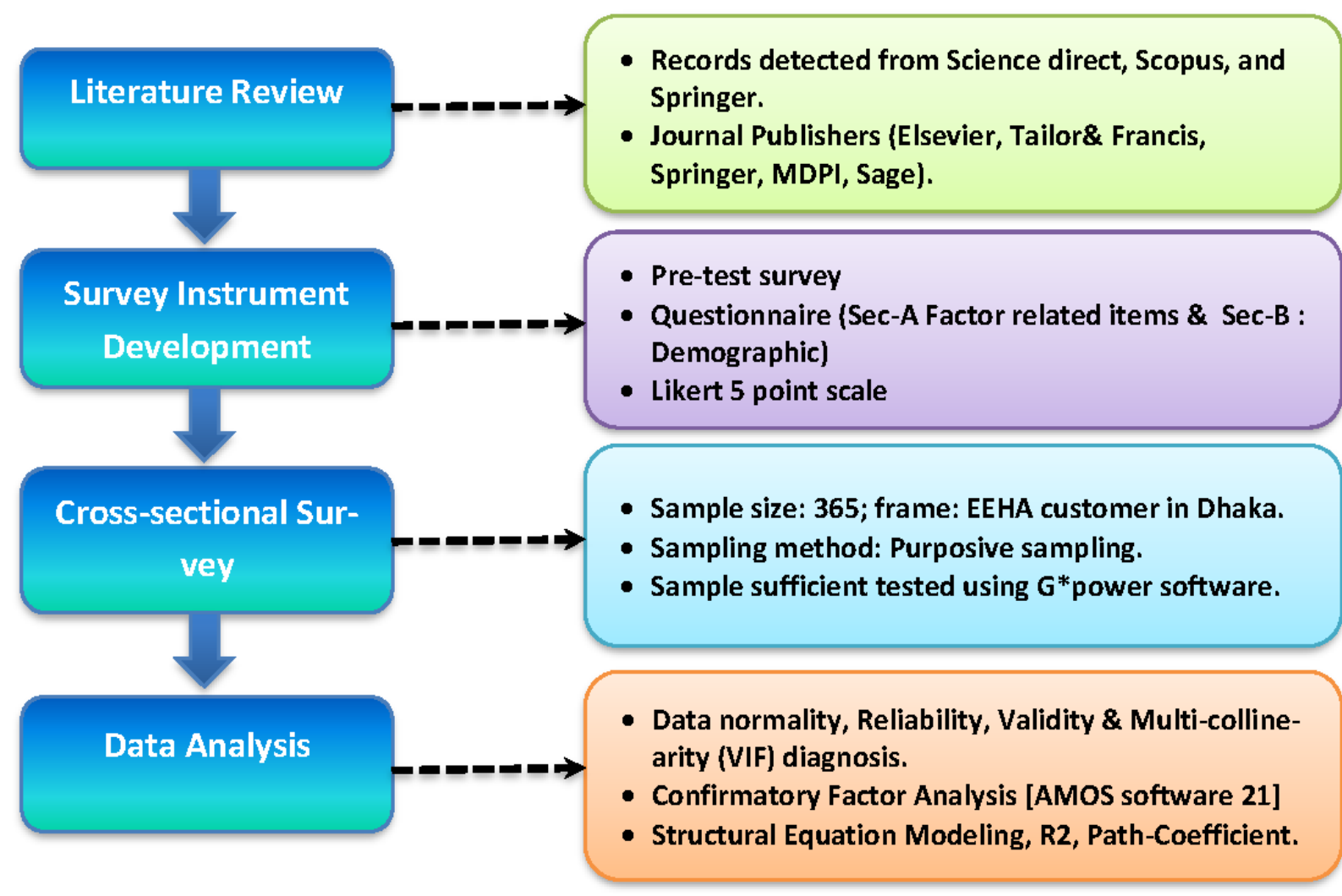

Figure 2. Flowchart of Research Methodology [Source: authors' illustration].

\subsection{Sample and Data Collection Procedures}

The demography of this study comprises Dhaka customers who are believed to be more informed and cautious in their purchase decisions. Also, compared to other cities in Bangladesh, Dhaka is better positioned in terms of purchasing power. The survey obtained the most data from superstores such as Alesha Mart, Mostafa Mart, and Unimart, and also from Dhaka New Market, which specializes in the sales of home appliances such as electrical kitchen appliances, cooling, and heating appliances, etc. The questionnaire survey was structured.

The study selected respondents based on a purposive sampling strategy. As part of the pre-test study, ten questionnaires were distributed to researchers, and before the final data gathering, a few modifications were implemented based on recommendations from the pre-test study. The minimal sample size was determined using the $\mathrm{G}^{*}$ power tool for priory sample size sufficiency [96] and was subsequently used to determine the required number of respondents for the study. Cohen [97] suggested a sample size of 153 for seven independent constructs or predictors $\left(\mathrm{f}^{2}=0.15\right.$ for effect size, $=0.05$ for error type 1 , and $B=0.20$ for error type 2), while Barclay et al. [98] established a tenfold sample rule in which the maximum number of indicators utilized in the SEM method was multiplied by ten. Going with these criteria, the survey required $240(10 \times 24)$ responders. However, 400 respondents were reached using the non-probability convenience selection approach to mitigate the potential difficulties associated with small sample sizes. Despite this, 365 samples were subsequently picked after the incomplete inquiries were screened, blotting out incomplete data (23 responses) and screened-out responses (12 responses) in 
the process. We have considered convenience sampling as a viable alternative owing to its lower costs and convenience of obtaining requisite responses.

\subsection{Development of the Questionnaire}

Data was obtained via a structured questionnaire, which was adapted from various past research works and contained 29 questions, including a demographic profile in Section 2. Eco-labeling was measured using the items from the conducted study by Neves \& Oliveira [45], with three items for assessing the purchase intention being adapted from the conducted study by Ali et al. [99]. The 3-items of environmental concern, environmental knowledge, and attitude were adapted from Li et al. [25]. The green self-identity was culled from Neves \& Oliveira [45] \& Zheng et al. [45]. The PBC and subjective norms of the constructs were assessed using the items obtained from Zhao et al. [68] and Bhutto et al. [66] accordingly (Appendix A). Furthermore, changes were made to the wordings to fit the organic food perspective. All the items were then measured using a five-point Likert's scale, where (1) represented 'strongly disagree' and (5), 'strongly agree.' In addition, respondents were quizzed on demographic parameters, such as age, profession, education, income, and gender.

\subsection{Statistical Analysis}

The theoretical framework was investigated using empirical data that was processed with the aid of the SPSS 25, MS-Excel, and AMOS statistical software version 21. There were four indicators analyzed to ensure the validity of the questionnaire survey to determine the effectiveness of the questionnaire items: construct validity, convergent validity, discriminant validity, and questionnaire reliability. Factor loading and cross-loading are both indicators of construct validity. A study's convergent validity can be seen in the factor loading, combined reliability, and average variance extracted. The differences between the average variance extracted and the correlation coefficients between variables reveal discriminant validity. Cronbach's alpha coefficient and composite reliability reflect the questionnaire's reliability. Besides, to assess the data normality, descriptive statistics such as mean, standard deviation, skewness, and kurtosis were used. The study used Variance Inflation Factor (VIF) measures, the severity of multicollinearity, how much the behavior (variance) of an independent variable is influenced, or inflated, by its interaction/correlation with the other independent variables. All parameters were determined by applying the final survey data to SPSS 25 and MS-Excel software.

The structural model was evaluated using the AMOS 21.0 software package, which tested the relationships between the hypothesized constructs. Anderson and Gerbing [100] developed a two-stage structural equation modeling (SEM) technique, in which a confirmatory factor analysis (CFA) was conducted in the first step to verify the reliability and validity of the measurement model. In the second step of the whole structural model, the overall fitness and hypothesized linkages were evaluated using the standardized $(\beta)$ and $p$-value regressions using AMOS software relying on the same data set (final survey data). The justification of adopting a two-stage approach, firstly, is to keep the measurement model(s) separate from the structural part during estimation so that they cannot influence each other. Traditionally, maximum likelihood fits all parameters simultaneously. This can lead to interpretation issues for latent variables due to misspecification in the structural model. Secondly, it assists in locating the problems for an unfit model. Convergence issues allow researchers to identify problematic measurement models (s) if it occurs in the first step. If the model fails to converge in the second step, the problem is structural [100].

\section{Results}

The result section covers the demographic profile of the respondents, reliability, and validity of constructs, followed by the confirmatory factor analysis, structural equation modeling, and moderation analysis. 


\subsection{Demographics Profile}

A high proportion (53.2\%) of the responders was males. Similarly, the majority $(47.7 \%)$ were graduates, while $31.3 \%$ had only secondary education or lower. Approximately $44.4 \%$ of the responders were private service holders, while $22.6 \%$ were government service holders, followed by the self-employed (11.7\%) and students $(11.1 \%)$. With regards to income level, approximately $53.7 \%$ earned between $\$ 470$ and $\$ 705$, while $20 \%$ received between $\$ 235$ and $\$ 470$ monthly. The lower-earning was $\$ 235$ or below constitutes around $4.5 \%$ of the total respondents. The age composition of the population revealed a larger proportion $(44.6 \%)$ of participants as being aged between 30 and 40 years, followed by $40-50$ years $(25.3 \%)$, indicating that the respondents were mature enough to remark on the issues addressed in the study (Table 2).

Table 2. Respondents' Profile.

\begin{tabular}{|c|c|c|c|c|c|c|c|}
\hline Aspects & Classification & F & $\%$ & Aspects & Classification & F & $\%$ \\
\hline \multirow{2}{*}{ Gender } & Male & 194 & 53.2 & \multirow{5}{*}{$\begin{array}{c}\text { Income } \\
\text { (\$1 equals Tk. 85) }\end{array}$} & Up to $\$ 235$ & 16 & 4.5 \\
\hline & Female & 171 & 46.8 & & $\$ 235-\$ 470$ & 73 & 20.0 \\
\hline \multirow{5}{*}{ Age } & $<20$ & 38 & 10.4 & & $\$ 470-\$ 705$ & 196 & 53.7 \\
\hline & $20-30$ & 55 & 15.0 & & $\$ 705-\$ 940$ & 57 & 15.5 \\
\hline & $30-40$ & 163 & 44.6 & & $>940$ & 23 & 6.3 \\
\hline & $40-50$ & 92 & 25.3 & \multirow{6}{*}{ Profession } & \multirow{2}{*}{ Student } & \multirow{2}{*}{41} & \multirow{2}{*}{11.1} \\
\hline & $>50$ & 17 & 4.7 & & & & \\
\hline \multirow{4}{*}{ Educational level } & No formal education & 39 & 10.6 & & Entrepreneurs & 37 & 10.2 \\
\hline & Higher Secondary or below & 114 & 31.3 & & Govt. Job holders & 82 & 22.6 \\
\hline & Graduate & 174 & 47.7 & & Private Jobs & 162 & 44.4 \\
\hline & Postgraduate and above & 38 & 10.4 & & Self-employed & 43 & 11.7 \\
\hline
\end{tabular}

$\$=$ indicates the US. Dollar. Source: Selected output of SPSS 25.0.

\subsection{Measurement Model (Reliability and Validity)}

The assessment of the measurement model was undertaken to estimate the validity and internal consistency of the construct. The construct validity was examined based on the Average Variance Extracted (AVE) and composite reliability. Table 3 shows the reliability and convergent validity measures where item loading is extracted from confirmatory factor analysis, the Cronbach alpha measuring construct reliability calculated using SPSS software 25 . The composite reliability and AVE are the validity measure extracted from the MS-excel spreadsheet formula. All the constructs (Table 3) have AVE values higher than 0.5, implying convergent validity [98,101].

Table 4 represents the discriminant validity tested with the popular Fornel Larker method that used correlations assessment via SPSS software. The results of the analysis (Table 4) indicate discriminant validity, as the value of the AVE's square root in the diagonal exceeds other constructs off-diagonal [101]. The value of CR and Cronbach's Alpha-which was greater than 0.7 -indicated a good model and was considered highly acceptable for the early stages of the research [102] (Table 3). The constructs of this study are deemed to be statistically satisfactory, as the CR and alpha values exceed the cut-off values earlier stated. 
Table 3. Reliability and convergent validity.

\begin{tabular}{|c|c|c|c|c|c|}
\hline Constructs & Item & Item Loading & $\begin{array}{c}\text { Cronbach Alpha } \\
(\alpha)\end{array}$ & $\begin{array}{l}\text { Composite } \\
\text { Reliability }\end{array}$ & $\begin{array}{c}\text { Average Variance } \\
\text { Explained }\end{array}$ \\
\hline \multirow{3}{*}{ Eco-Labeling } & LB1 & 0.747 & \multirow{3}{*}{0.867} & \multirow{3}{*}{0.877} & \multirow{3}{*}{0.707} \\
\hline & LB2 & 0.777 & & & \\
\hline & LB3 & 0.979 & & & \\
\hline \multirow{3}{*}{ Buying Intention } & BI1 & 0.854 & \multirow{3}{*}{0.868} & \multirow{3}{*}{0.838} & \multirow{3}{*}{0.635} \\
\hline & BI2 & 0.835 & & & \\
\hline & BI3 & 0.691 & & & \\
\hline \multirow{3}{*}{ Perceived Behavioral Control } & PBC1 & 0.893 & \multirow{3}{*}{0.907} & \multirow{3}{*}{0.908} & \multirow{3}{*}{0.767} \\
\hline & PBC2 & 0.845 & & & \\
\hline & PBC3 & 0.889 & & & \\
\hline \multirow{3}{*}{ Environmental Concern } & EC1 & 0.792 & \multirow{3}{*}{0.893} & \multirow{3}{*}{0.897} & \multirow{3}{*}{0.745} \\
\hline & $\mathrm{EC} 2$ & 0.905 & & & \\
\hline & $\mathrm{EC} 3$ & 0.888 & & & \\
\hline \multirow{3}{*}{ Environmental Knowledge } & EK1 & 0.719 & \multirow{3}{*}{0.796} & \multirow{3}{*}{0.897} & \multirow{3}{*}{0.745} \\
\hline & EK2 & 0.810 & & & \\
\hline & EK3 & 0.743 & & & \\
\hline \multirow{3}{*}{ Subjective Norms } & SN1 & 0.845 & \multirow{3}{*}{0.864} & \multirow{3}{*}{0.864} & \multirow{3}{*}{0.680} \\
\hline & SN2 & 0.850 & & & \\
\hline & SN3 & 0.777 & & & \\
\hline \multirow{3}{*}{ Attitude } & AT1 & 0.786 & \multirow{3}{*}{0.907} & \multirow{3}{*}{0.861} & \multirow{3}{*}{0.674} \\
\hline & AT2 & 0.839 & & & \\
\hline & AT3 & 0.836 & & & \\
\hline \multirow{3}{*}{ Green Self-Identity } & GSI1: & 0.833 & \multirow{3}{*}{0.831} & \multirow{3}{*}{0.876} & \multirow{3}{*}{0.702} \\
\hline & GSI2: & 0.852 & & & \\
\hline & GSI3: & 0.828 & & & \\
\hline
\end{tabular}

Source: Selected output of SPSS 25.0.

Table 4. Discriminant Validity (Fornel Larker Method).

\begin{tabular}{|c|c|c|c|c|c|c|c|c|}
\hline & LB & EK & EC & SN & PBC & AT & GSI & BI \\
\hline Labeling (LB) & 0.841 & & & & & & & \\
\hline Environmental Knowledge (EK) & $0.584^{* *}$ & 0.863 & & & & & & \\
\hline Environmental Concern (EC) & $0.659^{* *}$ & $0.614^{* *}$ & 0.863 & & & & & \\
\hline Subjective Norms (SN) & $0.638^{* *}$ & $0.620 * *$ & $0.690 * *$ & 0.825 & & & & \\
\hline Perceived Behavioral Control (PBC) & $0.134^{*}$ & $0.189 * *$ & $0.268^{* *}$ & $0.226^{* *}$ & 0.876 & & & \\
\hline Attitude (AT) & $0.676^{* *}$ & $0.675^{* *}$ & $0.715^{* *}$ & $0.729 * *$ & $0.206^{* *}$ & 0.821 & & \\
\hline Green Self-identity (GSI) & $0.599 * *$ & $0.619 * *$ & $0.720 * *$ & $0.642^{* *}$ & $0.164 * *$ & $0.752 * *$ & 0.838 & \\
\hline Buying Intention (BI) & $0.670 * *$ & $0.692 * *$ & $0.718 * *$ & $0.675^{* *}$ & $0.418^{* *}$ & $0.743^{* *}$ & $0.671 * *$ & 0.797 \\
\hline
\end{tabular}

(Note: Bold indicates the square root of AVE. ** Correlation is significant at the 0.01 level (2-tailed). *. Correlation is significant at the 0.05 level (2-tailed). Source: Selected output of SPSS 25.0.

For robustness, this study also measured the HTMT value due to its supremacy over Fornell-Larcker in various situations [103]. Table 5 indicates the measurement of HTMT ratio calculated with the help of individual item's correlation and using HTMT formula 
in the MS Excel software. The outcome recorded a value lower than $0.85 / 0.90$, implying the absence of a discriminant validity problem [103]. Since the present study satisfies the threshold value specified in Table 5, it can be affirmed that the reliability and validity suggested by these analyses are appropriate.

Table 5. Discriminant Validity using Heterotrait-Monotrait Ratio (HTMT).

\begin{tabular}{|c|c|c|c|c|c|c|c|c|}
\hline & LB & EK & EC & $\mathrm{SN}$ & PBC & $\mathrm{AT}$ & GSI & BI \\
\hline \multicolumn{9}{|l|}{ LB } \\
\hline EK & 0.703 & & & & & & & \\
\hline $\mathrm{EC}$ & 0.749 & 0.728 & & & & & & \\
\hline $\mathrm{SN}$ & 0.736 & 0.749 & 0.786 & & & & & \\
\hline PBC & 0.152 & 0.226 & 0.300 & 0.258 & & & & \\
\hline $\mathrm{AT}$ & 0.762 & 0.794 & 0.834 & 0.824 & 0.230 & & & \\
\hline GSI & 0.720 & 0.782 & 0.823 & 0.777 & 0.196 & 0.817 & & \\
\hline BI & 0.768 & 0.830 & 0.828 & 0.775 & 0.472 & 0.831 & 0.799 & \\
\hline
\end{tabular}

\subsection{Testing Normality, Multicollinearity, and Coefficient of Determination}

Table 6 highlighted data normality, Multicollinearity, and coefficient of determination of constructs. The applied tools, mean, standard deviation, skewness kurtosis, and VIF, were extracted using the descriptive statistics option of SPSS 25. The R square values were obtained from the AMOS 21 output at the time of structural modeling assessment. In terms of normality, the results were good, as no issues were recorded from the variance obtained from the normality assessment. The skewness and kurtosis values were less than \pm 3 and \pm 10 [104], respectively (Table 6). The effective technique involving the assessment of the variance inflation factor (VIF) was utilized as recommended by Kleinbaum et al. [105] to determine the presence of multicollinearity amongst the independent variables. The results revealed that the VIF range varies from 1.00 to 2.582 , which is substantially below 10. Therefore, this suggests that multicollinearity is not a concern in this investigation.

The R square analyzes the explanatory capacities of models by identifying the endogenous variables highlighted as determining coefficients. According to Cohen [106], the $R^{2}$ value of the endogenous variable is substantial when the value is above 0.26 and up to 0.13 is regarded as moderate. However, a value below 0.13 is considered weak. The $\mathrm{R}^{2}$ estimates of each endogenous value reported in the research in Table 6 are based on the conditions specified by Falk and Miller [107], which demonstrate that the proposed model falls within a high explanatory power range with an exception of the $\mathrm{PBC}$, which has low predicting power.

Table 6. Variance Inflation Factor (VIF) \& $R^{2}$ Value.

\begin{tabular}{|c|c|c|c|c|c|c|c|c|c|c|}
\hline & \multirow{2}{*}{ Mean } & \multirow{2}{*}{ Std. Deviation } & \multirow{2}{*}{ Skewness } & \multirow{2}{*}{ Kurtosis } & \multicolumn{4}{|c|}{ VIF } & \multicolumn{2}{|c|}{$\mathbf{R}^{2}$} \\
\hline & & & & & AT & BI & PBC & $\mathrm{SN}$ & Values & Strength \\
\hline LB & 3.305 & 0.7534 & -0.259 & -0.076 & 2.087 & & & & & \\
\hline EK & 3.080 & 0.752 & -0.329 & -0.438 & 1.905 & 1.967 & & & & \\
\hline $\mathrm{EC}$ & 3.280 & 0.904 & -0.243 & -0.064 & 2.391 & & 1.00 & 1.00 & & \\
\hline $\mathrm{SN}$ & 3.426 & 0.779 & -0.456 & 0.323 & 2.320 & 2.303 & & & & \\
\hline PBC & 2.587 & 1.089 & 0.620 & -0.652 & & 1.060 & & & 0.09 & Low \\
\hline $\mathrm{AT}$ & 3.342 & 0.812 & -0.485 & 0.309 & & 2.582 & & & 0.70 & High \\
\hline GSI & 3.460 & 0.744 & -0.494 & 0.781 & & & & & 0.61 & High \\
\hline BI & 3.298 & 0.828 & -0.300 & -0.375 & & & & & 0.77 & High \\
\hline
\end{tabular}




\subsection{Confirmatory Factor Analysis and Common Method Bias}

Table 7 explores the CFA and Structural model's fit indices extracted from the AMOS 21 software to verify how fits these models are. In the measurement model, the confirmation of factors was undertaken using the confirmatory factor analysis (CFA), and the resulting CFA model (Table 5) produced good fit indices: $\chi^{2} / \mathrm{df}=2.531$, Goodness of Fit Index $(\mathrm{GFI})=0.924$, Tucker-Lewis Index $(\mathrm{TLI})=0.933$, IFI $=0.922$, comparative fit index $(\mathrm{CFI})=0.942, \mathrm{NFI}=0.914$, and root mean square error of approximation $(\mathrm{RMSEA})=0.069$. The $t$-values corresponding to all the items were significant at a level lower than $5 \%$.

Based on the specified guidelines by Harman [108], common method bias was checked using the Harman's single-factor analysis approach, which relies on the factor analysis method. The single factor represented $31.3 \%$ of the variance in the factors, which was lower than the $50 \%$ threshold. This affirmed the absence of the common method bias.

Table 7. Results of the CFA and structural model with standards.

\begin{tabular}{lcccc}
\hline Fit Indices & $\begin{array}{c}\text { Measurement Values } \\
\text { for CFA }\end{array}$ & $\begin{array}{c}\text { Meas. Values for } \\
\text { Structural Model }\end{array}$ & \multicolumn{2}{c}{ Standards with Sources } \\
\hline$\chi^{2} / \mathrm{df}$ & 2.531 & 2.854 & $<3$ & {$[109]$} \\
\hline IFI & 0.922 & 0.938 & $>0.900$ & {$[110]$} \\
\hline NFI & 0.914 & 0.909 & $>0.900$ & {$[110]$} \\
\hline CFI & 0.942 & 0.938 & $>0.900$ & {$[111]$} \\
\hline GFI & 0.924 & 0.911 & $>0.900$ & {$[110]$} \\
\hline AGFI & 0.918 & 0.904 & $>0.900$ & {$[101]$} \\
\hline TLI & 0.933 & 0.926 & $\geq 0.90$ & {$[112]$} \\
\hline SRMR & 0.055 & 0.061 & $<0.080$ & {$[110]$} \\
\hline RMSEA & 0.069 & 0.073 & $<0.080$ & {$[112,113]$} \\
\hline
\end{tabular}

Source: Selected output of AMOS 21.0.

\subsection{Structural Modeling}

The structural model of this analysis is illustrated in Figure 3. As the calculation was successfully carried out in the CFA test of the measurement model, the validation of the structural model was used to check the goodness of fit indices of the proposed model. The outcome of the SEM reveals (Table 7) that the conceptual framework exhibits an excellent data fit $\left(\chi^{2} / \mathrm{df}=2.854\right)$. The realized value of the Root Mean Square Error Approximation (RMSEA) was 0.073, which justifies the cut-off value of less than 0.08 [114]. Other fit indices like the CFI, GFI, IFI, and TLI met the standard of 0.9 and higher [113].

Table 8 highlighted the statistic of path model using SEM via AMOS 21.0 software to find the path relationship among constructs as hypothesized. The results (Table 8 ) indicated that environmental concern influences the subjective norms $(\beta=0.783 ; t=13.069)$, perceived behavioral control $(\beta=0.304 ; t=5.142)$, and attitude $(\beta=0.489 ; t=6.029)$. Likewise, the AMOS output (Table 6) values indicated that the existent relationship between environmental knowledge $(\beta=0.284 ; t=6.043)$, subjective norms $(\beta=0.313 ; t=3.924)$, eco-labeling $(\beta=0.206 ; t=5.057)$ and attitude were significant. In addition to that, environmental knowledge $(\beta=0.295 ; \mathrm{t}=5.810)$, subjective norms $(\beta=0.172 ; \mathrm{t}=2.533 ; p<0.05)$, attitude $(\beta=0.497 ; t=6.653)$, perceived behavioral control $(\beta=0.324 ; t=7.636)$ and buying intention were also found to be significant. Therefore, we accept hypotheses 1 to 10 , all of which are significance at the $1 \%$ level except for $\mathrm{H}_{7}$, which exhibits significance at the $5 \%$ level. 


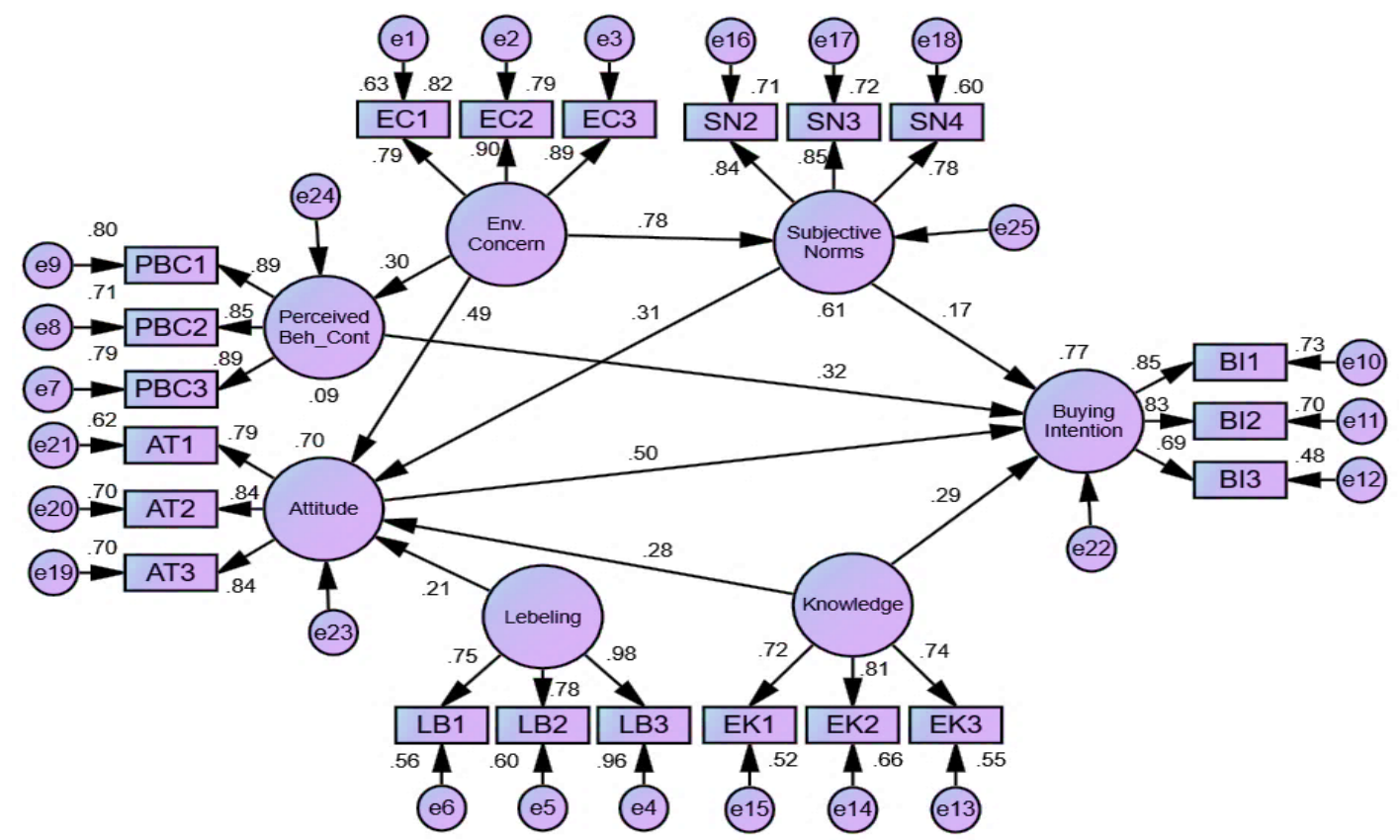

Figure 3. Structural Model [Source: Selected output of AMOS 21.0].

Table 8. Structural Model and the Hypothesis Testing Result.

\begin{tabular}{|c|c|c|c|c|c|}
\hline Hypotheses & STD Beta & STD Error & $t$-Values & $p$-Values & Significance $(p<0.05)$ \\
\hline $\mathrm{H} 1: \mathrm{EC} \rightarrow \mathrm{SN}$ & 0.783 & 0.055 & $13.069^{* * *}$ & 0.000 & Supported \\
\hline $\mathrm{H} 2: \mathrm{EC} \rightarrow \mathrm{AT}$ & 0.489 & 0.065 & $6.029 * * *$ & 0.000 & Supported \\
\hline $\mathrm{H} 3: \mathrm{EC} \rightarrow \mathrm{PBC}$ & 0.304 & 0.079 & $5.142 * * *$ & 0.000 & Supported \\
\hline $\mathrm{H} 4: \mathrm{EK} \rightarrow \mathrm{AT}$ & 0.284 & 0.045 & $6.043^{* * *}$ & 0.000 & Supported \\
\hline $\mathrm{H} 5: \mathrm{EK} \rightarrow \mathrm{BI}$ & 0.295 & 0.049 & $5.810 * * *$ & 0.000 & Supported \\
\hline $\mathrm{H6}: \mathrm{SN} \rightarrow \mathrm{AT}$ & 0.313 & 0.071 & $3.924^{* * *}$ & 0.000 & Supported \\
\hline $\mathrm{H} 7: \mathrm{SN} \rightarrow \mathrm{BI}$ & 0.172 & 0.060 & $2.533 * *$ & 0.011 & Supported \\
\hline $\mathrm{H} 8: \mathrm{LB} \rightarrow \mathrm{AT}$ & 0.206 & 0.031 & $5.057^{* * *}$ & 0.000 & Supported \\
\hline $\mathrm{H9}: \mathrm{AT} \rightarrow \mathrm{BI}$ & 0.497 & 0.075 & $6.653^{* * *}$ & 0.000 & Supported \\
\hline $\mathrm{H} 10: \mathrm{PBC} \rightarrow \mathrm{BI}$ & 0.324 & 0.026 & $7.636^{* * *}$ & 0.000 & Supported \\
\hline H11: GSI*AT $\rightarrow$ BI & 0.289 & 0.039 & $6.324^{* * *}$ & 0.000 & Supported \\
\hline $\mathrm{H} 12: \mathrm{EK}^{*} \mathrm{AT} \rightarrow \mathrm{BI}$ & 0.018 & 0.172 & 0.606 & 0.237 & Not Supported \\
\hline
\end{tabular}

** Significant at $5 \%$ level, ${ }^{* * *}$ Significant at $1 \%$ level, Source: Selected output of AMOS 21.0.

\subsection{The Moderation of Green Self-Identity and Environmental Knowledge}

The moderation effect was assessed based on the interaction effects of the variables. Figure 4 illustrates the moderation relationship among hypothesized variables using the Sobel test approach applying MS-Excel Spreadsheet. The study results (Figure 4 and Table 8 ) revealed that the green self-identity moderates the association between the attitude and purchase intention $(\beta=0.289, \mathrm{t}=6.324, p<0.01)$, while in contrast, the environmental knowledge does not moderate the association between attitude $(\beta=0.018, \mathrm{t}=0.606$, $p>0.05)$ and purchase intention. Therefore, $\mathrm{H}_{11}$ is validated while $\mathrm{H}_{12}$ is rejected. A higher green self-identity influences buying intention when a consumer is more inclined to purchase EEHA. 

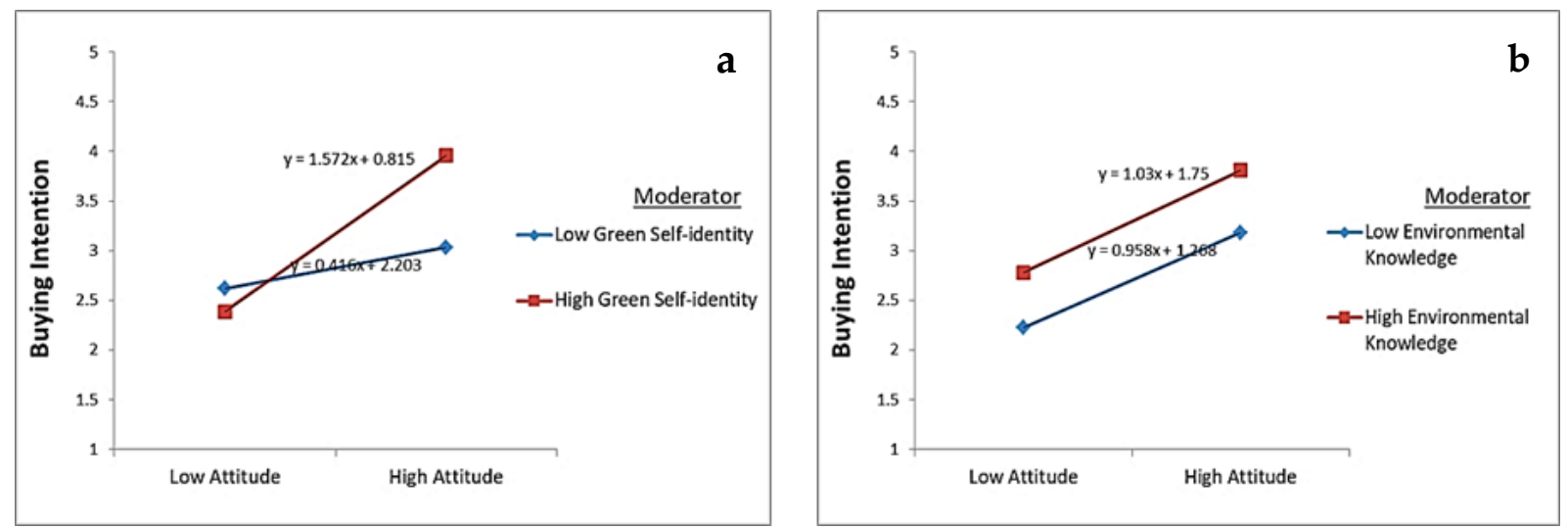

Figure 4. Interaction of (a) green self-identity is significant (b) environmental knowledge is insignificant between attitude and buying intention relationships, Source: Sobel test output.

\section{Discussion}

The study endeavored to incorporate additional cognitive constructs such as environmental concern, environmental knowledge, eco-labeling, and green self-identity along with the original TPB variables. In this proposed model, the $\mathrm{R}^{2}$ value of behavioral intention is 0.77 , which is greater than the values of 0.319 found in the original TPB model [115]. These results showed that because extended TPBs can perceive behavioral intention, the proposed model is generally adequate, comprehensive, and functional for comprehending EEHA product purchases.

According to the outcome of this study, environmental concern influences the subjective norms, perceived behavioral control, and attitude towards the purchase of EEHA in Bangladesh, thus validating Hypotheses 1-3. This signifies that the deeper the environmental concern expressed by the customers, the greater the external influence on purchase, internal motivation, and attitude towards the purchase of energy-efficient products, hence corroborating the previous research $[23,24,74,116]$. The results ( $\mathrm{H} 4$ and $\mathrm{H} 5)$ also revealed that environmental knowledge led to a more favorable attitude and intention towards the purchase of energy-efficient products in Bangladesh, which is complementary to the conducted study by China's Liu et al. [117]. This implies that customers tend to become more self-reliant in formulating opinions and making judgments when they are equipped with knowledge about the EEHA in Bangladesh perspectives.

The empirical assessment in this study identified the subjective norms as being of significant influence on customers' attitudes towards the purchase and buying intention of energy-efficient home appliances (H6 and H7). This result is in line with prior studies [118,119], which connotes that a higher social influence will result in a higher buying attitude and purchase intention of EEHA products in Bangladesh. It is noted that subjective norm is observed as the lowest relationship strength (0.172) with behavioral intention. Likewise, consistent with past studies [87], energy labeling is a determinant factor of attitude, which validates Hypothesis 8 . This result stresses that the access of people to information about a product's energy efficiency via the use of labeling will result in their tendency to make more purchases. As expected and in line with previous works of literature $[23,24,66,99]$, attitude and perceived behavioral control are key drivers of the purchase intention of EEHA products. This validates Hypotheses 9 and 10, indicating that a favorable attitude and higher PBC enhance the purchase intention of EEHA products. However, attitude is found as the highest strength (0.497) of relationship with the behavioral intention followed by the perceived behavioral control ( 0.324$)$.

This study endorses the moderating role of the green self-identity between attitude and buying intention, implying that an individual having a greater level of green selfidentity holds a stronger conviction to be more eco-friendly and is thus more inclined to act in an eco-friendly manner (H11). However, contrary to the study conducted by Cinjarevi'c 
et al. [94], environmental knowledge failed to moderate the positive association between the attitude and purchase intention of EEHA products (H12).

\section{Implications of the Study}

This research has contributed to the extant literature in numerous ways. First, based on the researcher's knowledge, this is the first research to address the buying intention exhibited by Bangladeshis towards energy-efficient home appliance products. Although some research on this issue abounds in South Asian countries and other regions, studies from the perspective of developing countries such as Bangladesh are lacking. Second, the attitude-intention gap is a pressing issue experienced in individual behavior models, particularly eco-friendly products [37]. However, consumers express a highly positive attitude towards eco-product when quizzed, indicating a deficiency in intention-behavior, as many of these attitudes do not transform into intention or behavior. The current study addressed the issue to find possible reasons for such gaps in Bangladesh by incorporating green self-identity and environmental knowledge variables in the research framework.

Third, the current study contributes to academia by establishing the moderating roles of green self-identity between attitude and buying intention. Existing research works mainly regard the green self-identity as having a moderating effect on the consumption value, intention or savings, label, operational and maintenance co-benefits, and intention, while overlooking the moderating impact of the green self-identity between attitude and intention using the TPB model. To the best of the author's knowledge, this study is one of the first to empirically examine how green self-identity moderates attitude-intention relationships. This knowledge will help to provide an understanding of the role of consumers green emotion to bridge the attitude-intention gaps.

Fourth, this study contributes to recent studies that found subjective norm to be a determinant of both attitude and behavioral intentions $[118,119]$ in a single model in other fields. Rarely, the subjective norm was observed to be simultaneously significant with the attitude and intention, and none of the studies on the purchase of energy-saving home appliance products claimed to have both impacts simultaneously. This study established subjective norms as a very important predictor of the behavioral intention of the purchase of EEHA. This will strengthen the schools of thought that are of the belief that external influence (subjective norms) matters in the implementation of purchase decisions and those that advocate for the enhancement of community engagement by the companies in addition to the presence in the markets.

This study offers numerous practical implications for managers and policymakers. As the eco-label was proven to be associated with purchase behavior, the energy label must be placed on all equipment since it is a vital factor that individuals regard as premium. Therefore, the energy label must be visually appealing and indicate the energy categorization of the equipment. This recommendation may be more geared toward energy agencies. Second, the perceived behavioral control and green self-identity significantly influence the intention of residents to purchase EEHA. The buyers' belief in their ability to make decisions and control and their green emotions should be strategically targeted. Therefore, promotional campaigns should be actively undertaken by the seller to induce prospective buyers. The promotional activities could range from publicity, advertisement, and personal sales, to sales promotion like discounts to enable buyers to remain informed about the product and spur them to make a purchase decision.

Third, according to confirmed Hypotheses 1 to 5, environmental concern and environmental knowledge influence the buying attitude and subjective norm and ultimately influence the buying intention of EEHA. Equipped with the role of a private enterprise, the government should promote environmental education and awareness programs. This is critical to the enlightenment of residents to the essence of energy-saving and cutting emissions, logical use of mass platforms to promote knowledge about EEHA and ecological protection, and a continuous effort to change the attitude of residents toward EEHA and increase their purchase intention. Besides, with the proper regulations and 
policies on the development of local manufacturing companies of EEHA, a subsidiary policy should be undertaken to promote and enable startups to endure competition. It may involve the rendering of technical help, monetary incentives, and exemptions from taxes on energy-efficient imported technologies and equipment.

\section{Conclusions and Limitations}

This study investigated the factors influencing the buying intention of EEHA in Bangladesh. It confirmed that the environmental knowledge, subjective norms, attitude, and perceived behavioral control significantly affected consumers' buying intention of energy-efficient home appliances. The result revealed a significant relationship among environmental concern, environmental knowledge, subjective norms, eco-labeling, and attitude towards purchases. It also discovered that the green self-identity moderates the relationship between the buying intention and attitude of EEHA products, while environmental knowledge failed to moderate the same relationship.

This study examined the purchase intentions of green products and may be further extended to include the repurchase intention in the future to provide an insight into how consumers might be sustained. In this study, we used behavioral intentions to consume EEHA products. Future research can incorporate actual behavior to provide an understanding of how much intention transforms into actual activity. Finally, this research was limited to a sample of energy-efficient product customers in Dhaka, Bangladesh (Urban population). Therefore, to acquire a better understanding of the breadth and depth of consumer intention towards the purchase of EEHA in Bangladesh, a sample from other cities, including smaller towns and rural areas, is essential.

Author Contributions: Conceptualization, A.B.S., Y.L. and M.M.; methodology, A.B.S., M.M. and Y.L.; software, A.B.S. and M.M.; validation, Y.L., A.B.S. and M.M.; investigation, M.M., A.B.S. and Y.L.; resources, A.B.S., Y.L. and M.M.; data curation, M.M., A.B.S. and Y.L.; writing—original draft preparation, Y.L., A.B.S. and M.M.; writing-review and editing, Y.L., X.W. and M.M.; visualization, A.B.S., X.W. and Y.L.; supervision, X.W. and M.M.; Funding acquisition, Y.L. All authors have read and agreed to the published version of the manuscript.

Funding: This study was funded by the National Social Science Fund of China (grant no. 19BJY177).

Institutional Review Board Statement: Ethical review and approval were waived for this study due to the fact that there is no institutional review board or committee in Bangladesh. Besides, the study was conducted as per the guidelines of the Declaration of Helsinki. The research questionnaire was anonymous, and no personal information was gathered.

Informed Consent Statement: Oral consent was obtained from all individuals involved in this study.

Data Availability Statement: The data that support the findings of this study are available from the corresponding authors (A.B.S.) upon reasonable request.

Conflicts of Interest: The authors declare no conflict of interest.

Appendix A

Table A1. Survey Instruments.

\begin{tabular}{l}
\hline \multicolumn{1}{c}{ Constructs } \\
\hline Eco-Labeling \\
\hline LB1. The energy label is critical when purchasing a household appliance. \\
\hline LB2. When I purchase a household appliance, I carefully read the energy label. \\
\hline $\begin{array}{l}\text { LB3. I am more receptive to purchasing a household appliance with a high-energy efficiency rating } \\
\text { (above C, i.e., A or B) }\end{array}$
\end{tabular}


Table A1. Cont.

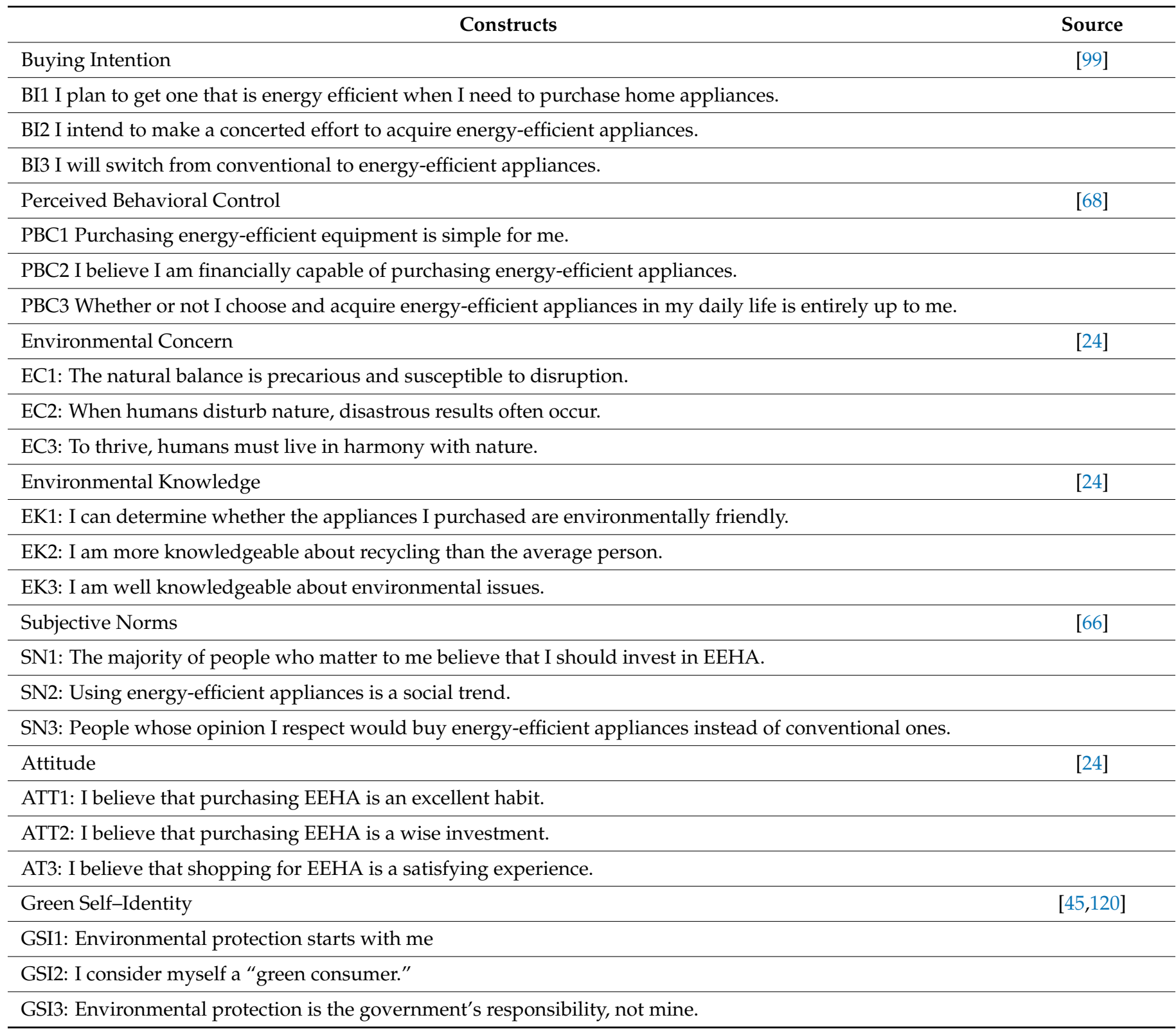

\section{References}

1. Ali, S.; Ullah, H.; Akbar, M.; Akhtar, W.; Zahid, H. Determinants of consumer intentions to purchase energy-saving household products in Pakistan. Sustainability 2019, 11, 1462. [CrossRef]

2. Sorrell, S. Reducing energy demand: A review of issues, challenges and approaches. Renew. Sustain. Energy Rev. 2015, 47, 74-82. [CrossRef]

3. Zhou, K.; Yang, S. Understanding household energy consumption behavior: The contribution of energy big data analytics. Renew. Sustain. Energy Rev. 2016, 56, 810-819. [CrossRef]

4. Ek, K.; Söderholm, P. The devil is in the details: Household electricity saving behavior and the role of information. Energy Policy 2010, 38, 1578-1587. [CrossRef]

5. Tan, C.-S.; Ooi, H.-Y.; Goh, Y.-N. A moral extension of the theory of planned behavior to predict consumers' purchase intention for energy-efficient household appliances in Malaysia. Energy Policy 2017, 107, 459-471. [CrossRef]

6. Wang, Z.; Zhang, B.; Li, G. Determinants of energy-saving behavioral intention among residents in Beijing: Extending the theory of planned behavior. J. Renew. Sustain. Energy 2014, 6, 53127. [CrossRef]

7. Mills, B.; Schleich, J. Analysis of Existing Data: Determinants for the Adoption of Energy-Efficient Household Appliances in Germany. In Sustainable Energy Consumption in Residential Buildings; Springer: Berlin/Heidelberg, Germany, 2013 ; pp. 39-67. 
8. Frederiks, E.R.; Stenner, K.; Hobman, E.V.; Fischle, M. Evaluating energy behavior change programs using randomized controlled trials: Best practice guidelines for policymakers. Energy Res. Soc. Sci. 2016, 22, 147-164. [CrossRef]

9. Park, E.; Kwon, S.J. What motivations drive sustainable energy-saving behavior?: An examination in South Korea. Renew. Sustain. Energy Rev. 2017, 79, 494-502. [CrossRef]

10. Ahmed, A.S.; Kumari, D.R.; Neeraja, T. Purchase Behavior of Women Consumers, towards Energy Efficient Household Products. Doctoral Dissertation, Univeristy Rajendranagar, Hyderabad, India, 2017.

11. Joshi, G.; Sen, V.; Kunte, M. Do Star Ratings Matter?: A Qualitative Study on Consumer Awareness and Inclination to Purchase Energy-Efficient Home Appliances. Int. J. Soc. Ecol. Sustain. Dev. 2020, 11, 40-55. [CrossRef]

12. Poortinga, W.; Steg, L.; Vlek, C.; Wiersma, G. Household preferences for energy-saving measures: A conjoint analysis. J. Econ. Psychol. 2003, 24, 49-64. [CrossRef]

13. Wai, C.W.; Mohammed, A.H.; Alias, B. Energy conservation: A conceptual framework of energy awareness development process. Malaysian J. Real Estate 2009, 1, 58-67.

14. Oikonomou, V.; Becchis, F.; Steg, L.; Russolillo, D. Energy saving and energy efficiency concepts for policy making. Energy Policy 2009, 37, 4787-4796. [CrossRef]

15. Abrahamse, W.; Steg, L. How do socio-demographic and psychological factors relate to households' direct and indirect energy use and savings? J. Econ. Psychol. 2009, 30, 711-720. [CrossRef]

16. Niemeyer, S. Consumer voices: Adoption of residential energy-efficient practices. Int. J. Consum. Stud. 2010, 34, 140-145. [CrossRef]

17. Pothitou, M.; Hanna, R.F.; Chalvatzis, K.J. Environmental knowledge, pro-environmental behaviour and energy savings in households: An empirical study. Appl. Energy 2016, 184, 1217-1229. [CrossRef]

18. Tanner, C.; Kast, S.W. Promoting Sustainable Consumption: Determinants of Green Purchases by Swiss Consumers. Psychol. Mark. 2003, 20, 883-902. [CrossRef]

19. Baldini, M.; Trivella, A.; Wente, J.W. The impact of socioeconomic and behavioural factors for purchasing energy-efficient household appliances: A case study for Denmark. Energy Policy 2018, 120, 503-513. [CrossRef]

20. Jain, S.K.; Kaur, G. Role of socio-demographics in segmenting and profiling green consumers: An exploratory study of consumers in India. J. Int. Consum. Mark. 2006, 18, 107-146. [CrossRef]

21. Jeong, G.; Kim, Y. The effects of energy efficiency and environmental labels on appliance choice in South Korea. Energy Effic. 2015, 8, 559-576. [CrossRef]

22. Lin, J.; Lobo, A.; Leckie, C. The role of benefits and transparency in shaping consumers' green perceived value, self-brand connection and brand loyalty. J. Retail. Consum. Serv. 2017, 35, 133-141. [CrossRef]

23. Zhang, L.; Fan, Y.; Zhang, W.; Zhang, S. Extending the theory of planned behavior to explain the effects of cognitive factors across different kinds of green products. Sustainability 2019, 11, 4222. [CrossRef]

24. Li, G.; Li, W.; Jin, Z.; Wang, Z. Influence of environmental concern and knowledge on households' willingness to purchase energy-efficient appliances: A case study in Shanxi, China. Sustainability 2019, 11, 1073. [CrossRef]

25. Hua, L.; Wang, S. Antecedents of consumers' intention to purchase energy-efficient appliances: An empirical study based on the technology acceptance model and theory of planned behavior. Sustainability 2019, 11, 2994. [CrossRef]

26. Chen, M.-F. Extending the theory of planned behavior model to explain people's energy savings and carbon reduction behavioral intentions to mitigate climate change in Taiwan-moral obligation matters. J. Clean. Prod. 2016, 112, 1746-1753. [CrossRef]

27. Yuriev, A.; Dahmen, M.; Paillé, P.; Boiral, O.; Guillaumie, L. Pro-environmental behaviors through the lens of the theory of planned behavior: A scoping review. Resour. Conserv. Recycl. 2020, 155, 104660. [CrossRef]

28. Davies, J.; Foxall, G.R.; Pallister, J. Beyond the intention-behaviour mythology: An integrated model of recycling. Mark. Theory 2002, 2, 29-113. [CrossRef]

29. Ertz, M.; Huang, R.; Jo, M.-S.; Karakas, F.; Sarigöllü, E. From single-use to multi-use: Study of consumers' behavior toward consumption of reusable containers. J. Environ. Manag. 2017, 193, 334-344. [CrossRef]

30. Ajzen, I. Constructing a TPB Questionnaire: Conceptual and Methodological Considerations; CiteSeer: Princeton, NJ, USA, 2002.

31. Rhodes, R.E.; Courneya, K.S. Investigating multiple components of attitude, subjective norm, and perceived control: An examination of the theory of planned behaviour in the exercise domain. Br. J. Soc. Psychol. 2003, 42, 129-146. [CrossRef]

32. Ajzen, I. The theory of planned behavior. Organ. Behav. Hum. Decis. Process. 1991, 50, 179-211. [CrossRef]

33. Ajzen, I. The theory of planned behavior: Frequently asked questions. Hum. Behav. Emerg. Technol. 2020, 2, 314-324. [CrossRef]

34. Al Mamun, A.; Mohamad, M.R.; Bin Yaacob, M.R.; Mohiuddin, M. Intention and behavior towards green consumption among low-income households. J. Environ. Manag. 2018, 227, 73-86. [CrossRef]

35. Sreen, N.; Purbey, S.; Sadarangani, P. Impact of culture, behavior and gender on green purchase intention. J. Retail. Consum. Serv. 2018, 41, 177-189. [CrossRef]

36. Kaffashi, S.; Shamsudin, M.N. Transforming to a low carbon society; an extended theory of planned behaviour of Malaysian citizens. J. Clean. Prod. 2019, 235, 1255-1264. [CrossRef]

37. Wiederhold, M.; Martinez, L.F. Ethical consumer behaviour in Germany: The attitude-behaviour gap in the green apparel industry. Int. J. Consum. Stud. 2018, 42, 419-429. [CrossRef]

38. Gleim, M.; Lawson, S.J. Spanning the gap: An examination of the factors leading to the green gap. J. Consum. Mark. 2014, 31, 503-514. [CrossRef] 
39. Vermeir, I.; Verbeke, W. Impact of values, involvement and perceptions on consumer attitudes and intentions towards sustainable consumption. J. Agric. Environ. Ethics 2006, 19, 169-194. [CrossRef]

40. Van der Werff, E.; Steg, L.; Keizer, K. It is a moral issue: The relationship between environmental self-identity, obligation-based intrinsic motivation and pro-environmental behaviour. Glob. Environ. Chang. 2013, 23, 1258-1265. [CrossRef]

41. Nigbur, D.; Lyons, E.; Uzzell, D. Attitudes, norms, identity and environmental behaviour: Using an expanded theory of planned behaviour to predict participation in a kerbside recycling programme. Br. J. Soc. Psychol. 2010, 49, 259-284. [CrossRef]

42. Gatersleben, B.; Murtagh, N.; Abrahamse, W. Values, identity and pro-environmental behaviour. Contemp. Soc. Sci. 2014, 9 , 374-392. [CrossRef]

43. Kashima, Y.; Paladino, A.; Margetts, E.A. Environmentalist identity and environmental striving. J. Environ. Psychol. 2014, 38, 64-75. [CrossRef]

44. Qasim, H.; Yan, L.; Guo, R.; Saeed, A.; Ashraf, B.N. The defining role of environmental self-identity among consumption values and behavioral intention to consume organic food. Int. J. Environ. Res. Public Health 2019, 16, 1106. [CrossRef] [PubMed]

45. Neves, J.; Oliveira, T. Understanding energy-efficient heating appliance behavior change: The moderating impact of the green self-identity. Energy 2021, 225, 120169. [CrossRef]

46. Mostafa, M.M. Gender differences in Egyptian consumers' green purchase behaviour: The effects of environmental knowledge, concern and attitude. Int. J. Consum. Stud. 2007, 31, 220-229. [CrossRef]

47. Polonsky, M.J.; Vocino, A.; Grau, S.L.; Garma, R.; Ferdous, A.S. The impact of general and carbon-related environmental knowledge on attitudes and behaviour of US consumers. J. Mark. Manag. 2012, 28, 238-263. [CrossRef]

48. Laroche, M.; Tomiuk, M.; Bergeron, J.; Barbaro-Forleo, G. Cultural differences in environmental knowledge, attitudes, and behaviours of Canadian consumers. Can. J. Adm. Sci. Can. Sci. l'Adm. 2002, 19, 267-282. [CrossRef]

49. Kollmuss, A.; Agyeman, J. Mind the gap: Why do people act environmentally and what are the barriers to pro-environmental behavior? Environ. Educ. Res. 2002, 8, 239-260. [CrossRef]

50. Kim, E.; Ham, S.; Yang, I.S.; Choi, J.G. The roles of attitude, subjective norm, and perceived behavioral control in the formation of consumers' behavioral intentions to read menu labels in the restaurant industry. Int. J. Hosp. Manag. 2013, 35, 203-213. [CrossRef]

51. Tarkiainen, A.; Sundqvist, S. Subjective norms, attitudes and intentions of Finnish consumers in buying organic food. Br. Food J. 2005, 107, 808-822. [CrossRef]

52. Ajzen, I.; Fishbein, M. Understing Attitudes and Predicting Social Behaviour; Prentice-Hall: Englewood Cliffs, NJ, USA, 1980.

53. Beck, L.; Ajzen, I. Predicting dishonest actions using the theory of planned behavior. J. Res. Personal. 1991, 25, 285-301. [CrossRef]

54. Verma, V.K.; Chandra, B. An application of theory of planned behavior to predict young Indian consumers' green hotel visit intention. J. Clean. Prod. 2018, 172, 1152-1162. [CrossRef]

55. Yadav, R.; Pathak, G.S. Determinants of consumers' green purchase behavior in a developing nation: Applying and extending the theory of planned behavior. Ecol. Econ. 2017, 134, 114-122. [CrossRef]

56. Nguyen, T.N.; Lobo, A.; Greenland, S. Energy efficient household appliances in emerging markets: The influence of consumers' values and knowledge on their attitudes and purchase behaviour. Int. J. Consum. Stud. 2017, 41, 167-177. [CrossRef]

57. Wang, Z.; Wang, X.; Guo, D. Policy implications of the purchasing intentions towards energy-efficient appliances among China's urban residents: Do subsidies work? Energy Policy 2017, 102, 430-439. [CrossRef]

58. Ha, H.; Janda, S. Predicting consumer intentions to purchase energy-efficient products. J. Consum. Mark. 2012, 29, 461-469. [CrossRef]

59. Hori, S.; Kondo, K.; Nogata, D.; Ben, H. The determinants of household energy-saving behavior: Survey and comparison in five major Asian cities. Energy Policy 2013, 52, 354-362. [CrossRef]

60. Wang, Z.; Sun, Q.; Wang, B.; Zhang, B. Purchasing intentions of Chinese consumers on energy-efficient appliances: Is the energy efficiency label effective? J. Clean. Prod. 2019, 238, 117896. [CrossRef]

61. Zainudin, N.; Siwar, C.; Choy, E.A.; Chamhuri, N. Evaluating the Role of Energy Efficiency Label on Consumers' Purchasing Behaviour. APCBEE Procedia 2014, 10, 326-330. [CrossRef]

62. Wang, P.; Liu, Q.; Qi, Y. Factors influencing sustainable consumption behaviors: A survey of the rural residents in China. J. Clean. Prod. 2014, 63, 152-165. [CrossRef]

63. Alam, S.S.; Hashim, N.H.N.; Rashid, M.; Omar, N.A.; Ahsan, N.; Ismail, M.D. Small-scale households renewable energy usage intention: Theoretical development and empirical settings. Renew. Energy 2014, 68, 255-263. [CrossRef]

64. Gaspar, R.; Antunes, D. Energy efficiency and appliance purchases in Europe: Consumer profiles and choice determinants. Energy Policy 2011, 39, 7335-7346. [CrossRef]

65. Wang, Z.; Zhang, B.; Yin, J.; Zhang, Y. Determinants and policy implications for household electricity-saving behaviour: Evidence from Beijing, China. Energy Policy 2011, 39, 3550-3557. [CrossRef]

66. Bhutto, M.Y.; Liu, X.; Soomro, Y.A.; Ertz, M.; Baeshen, Y. Adoption of energy-efficient home appliances: Extending the theory of planned behavior. Sustainability 2021, 13, 250. [CrossRef]

67. Zou, B.; Mishra, A.K. Appliance usage and choice of energy-efficient appliances: Evidence from rural Chinese households. Energy Policy 2020, 146, 111800. [CrossRef]

68. Zhao, C.; Zhang, M.; Wang, W. Exploring the influence of severe haze pollution on residents' intention to purchase energy-saving appliances. J. Clean. Prod. 2019, 212, 1536-1543. [CrossRef] 
69. Joshi, G.Y.; Sheorey, P.A.; Gandhi, A.V. Analyzing the barriers to purchase intentions of energy efficient appliances from consumer perspective. Benchmarking Int. J. 2019, 26, 1565-1580. [CrossRef]

70. Kim, W.; Ko, S.; Oh, M.; Choi, I.; Shin, J. Is an incentive policy for energy efficient products effective for air purifiers? The case of South Korea. Energies 2019, 12, 1664. [CrossRef]

71. Jaiswal, D.; Kant, R. Green purchasing behaviour: A conceptual framework and empirical investigation of Indian consumers. J. Retail. Consum. Serv. 2018, 41, 60-69. [CrossRef]

72. Crosby, L.A.; Gill, J.D.; Taylor, J.R. Consumer/voter behavior in the passage of the Michigan container law. J. Mark. 1981, 45, 19-32. [CrossRef]

73. Chen, M.F.; Tung, P.J. Developing an extended Theory of Planned Behavior model to predict consumers' intention to visit green hotels. Int. J. Hosp. Manag. 2014, 36, 221-230. [CrossRef]

74. Paul, J.; Modi, A.; Patel, J. Predicting green product consumption using theory of planned behavior and reasoned action. J. Retail. Consum. Serv. 2016, 29, 123-134. [CrossRef]

75. Oh, K.; Abraham, L. Effect of knowledge on decision making in the context of organic cotton clothing. Int. J. Consum. Stud. 2016, 40, 66-74. [CrossRef]

76. Chan, R.Y.K.; Lau, L.B.Y. Antecedents of green purchases: A survey in China. J. Consum. Mark. 2000, 17, 338-357. [CrossRef]

77. Flamm, B. The impacts of environmental knowledge and attitudes on vehicle ownership and use. Transp. Res. Part D Transp. Environ. 2009, 14, 272-279. [CrossRef]

78. Mostafa, M.M. Shades of green: A psychographic segmentation of the green consumer in Kuwait using self-organizing maps. Expert Syst. Appl. 2009, 36, 11030-11038. [CrossRef]

79. Barber, N.; Taylor, C.; Strick, S. Wine consumers' environmental knowledge and attitudes: Influence on willingness to purchase. Int. J. Wine Res. 2009, 1, 59-72. [CrossRef]

80. Latif, S.A.; Omar, M.S.; Bidin, Y.H.; Awang, Z. Role of environmental knowledge in creating pro-environmental residents. Procedia-Soc. Behav. Sci. 2013, 105, 866-874. [CrossRef]

81. Vicente-Molina, M.A.; Fernández-Sáinz, A.; Izagirre-Olaizola, J. Environmental knowledge and other variables affecting proenvironmental behaviour: Comparison of university students from emerging and advanced countries. J. Clean. Prod. 2013, 61, 130-138. [CrossRef]

82. Atkinson, L.; Rosenthal, S. Signaling the green sell: The influence of eco-label source, argument specificity, and product involvement on consumer trust. J. Advert. 2014, 43, 33-45. [CrossRef]

83. Prieto-Sandoval, V.; Alfaro, J.A.; Mejía-Villa, A.; Ormazabal, M. ECO-labels as a multidimensional research topic: Trends and opportunities. J. Clean. Prod. 2016, 135, 806-818. [CrossRef]

84. Shen, J.; Saijo, T. Does an energy efficiency label alter consumers' purchasing decisions? A latent class approach based on a stated choice experiment in Shanghai. J. Environ. Manag. 2009, 90, 3561-3573. [CrossRef]

85. Stadelmann, M.; Schubert, R. How do different designs of energy labels influence purchases of household appliances? A field study in Switzerland. Ecol. Econ. 2018, 144, 112-123. [CrossRef]

86. Cho, E.; Gupta, S.; Kim, Y. Style consumption: Its drivers and role in sustainable apparel consumption. Int. J. Consum. Stud. 2015, 39, 661-669. [CrossRef]

87. Simon, F.L. Marketing green products in the triad. Columbia J. World Bus. 1992, 27, 268-285.

88. Stets, J.E.; Burke, P.J. Identity theory and social identity theory. Soc. Psychol. Q. 2000, 63, 224-237. [CrossRef]

89. Conner, M.; Armitage, C.J. Extending the theory of planned behavior: A review and avenues for further research. J. Appl. Soc. Psychol. 1998, 28, 1429-1464. [CrossRef]

90. Van der Werff, E.; Steg, L.; Keizer, K. The value of environmental self-identity: The relationship between biospheric values, environmental self-identity and environmental preferences, intentions and behaviour. J. Environ. Psychol. 2013, 34, 55-63. [CrossRef]

91. Stets, J.E.; Biga, C.F. Bringing identity theory into environmental sociology. Sociol. Theory 2003, 21, 398-423. [CrossRef]

92. Cook, A.J.; Kerr, G.N.; Moore, K. Attitudes and intentions towards purchasing GM food. J. Econ. Psychol. 2002, $23,557-572$. [CrossRef]

93. Sparks, P.; Shepherd, R. Self-Identity and the Theory of Planned Behavior: Assesing the Role of Identification with "Green Consumerism". Soc. Psychol. Q. 1992, 55, 388-399. [CrossRef]

94. Činjarević, M.; Agić, E.; Peštek, A. When consumers are in doubt, you better watch out! the moderating role of consumer skepticism and subjective knowledge in the context of organic food consumption. Zagreb Int. Rev. Econ. Bus. 2018, 21, 1-14. [CrossRef]

95. Raju, P.S.; Lonial, S.C.; Mangold, W.G. Differential effects of subjective knowledge, objective knowledge, and usage experience on decision making: An exploratory investigation. J. Consum. Psychol. 1995, 4, 153-180. [CrossRef]

96. Faul, F.; Erdfelder, E.; Buchner, A.; Lang, A.-G. Statistical power analyses using G* Power 3.1: Tests for correlation and regression analyses. Behav. Res. Methods 2009, 41, 1149-1160. [CrossRef]

97. Vidaver-Cohen, D. Moral climate in business firms: A conceptual framework for analysis and change. J. Bus. Ethics 1998, 17, 1211-1226. [CrossRef]

98. Barclay, M.J.; Smith, C.W.; Watts, R.L. The determinants of corporate leverage and dividend policies. J. Appl. Corp. Financ. 1995, 7, 4-19. [CrossRef] 
99. Ali, M.R.; Shafiq, M.; Andejany, M. Determinants of consumers' intentions towards the purchase of energy efficient appliances in Pakistan: An extended model of the theory of planned behavior. Sustainability 2021, 13, 565. [CrossRef]

100. Anderson, J.C.; Gerbing, D.W. Structural equation modeling in practice: A review and recommended two-step approach. Psychol. Bull. 1988, 103, 411. [CrossRef]

101. Fornell, C.; Larcker, D.F. Structural Equation Models with Unobservable Variables and Measurement Error: Algebra and Statistics. J. Mark. Res. 1981, 18, 382-388. [CrossRef]

102. Akter, S.; D'Ambra, J.; Ray, P. Trustworthiness in mHealth information services: An assessment of a hierarchical model with mediating and moderating effects using partial least squares (PLS). J. Am. Soc. Inf. Sci. Technol. 2011, 62, 100-116. [CrossRef]

103. Henseler, J.; Ringle, C.M.; Sarstedt, M. A new criterion for assessing discriminant validity in variance-based structural equation modeling. J. Acad. Mark. Sci. 2015, 43, 115-135. [CrossRef]

104. Kline, R.B. Convergence of Structural Equation Modeling and Multilevel Modeling; Sage Publishing: Thousand Oaks, CA, USA, 2011.

105. Kleinbaum, D.G.; Kupper, L.L.; Muller, K.E. Applied Regression Analysys and Other Multivariable Methods. In Applied Regression Analysys and Other Multivariable Methods; Duxbury Press: Pacific Grove, CA, USA, 1988; p. 718.

106. Cohen, J. Statistical Power Analysis for the Behavioral Sciences; Lawrence Erlbaum Associates: Hillsdale, NJ, USA, $1988 ;$ pp. $20-26$.

107. Falk, R.F.; Miller, N.B. A Primer for Soft Modeling; University of Akron Press: Akron, OH, USA, 1992; ISBN 0962262846.

108. Harman, H.H. Modern Factor Analysis; University of Chicago Press: Chicago, IL, USA, 1976; ISBN 0226316521.

109. Holbert, R.L.; Stephenson, M.T. Structural Equation Modeling in the Communication Sciences, 1995-2000. Hum. Commun. Res. 2002, 28, 1995-2000. [CrossRef]

110. Bentler, P.M.; Bonett, D.G. Significance tests and goodness of fit in the analysis of covariance structures. Psychol. Bull. 1980, 88 , 588-606. [CrossRef]

111. Jöreskog, K.G.; Sörbom, D. LISREL 8: Structural Equation Modeling with the SIMPLIS Command Language; Scientific Software International: Skokie, IL, USA, 1993.

112. McDonald, R.P.; Ho, M.-H.R. Principles and practice in reporting structural equation analyses. Psychol. Methods $2002,7,64$. [CrossRef] [PubMed]

113. Bagozzi, R.P.; Yi, Y. On the evaluation of structural equation models. J. Acad. Mark. Sci. 1988, 16, 74-94. [CrossRef]

114. Browne, M.W.; Cudeck, R. Alternative ways of assessing model fit. In Testing Structural Equation Models; Bollen, K.A., Long, J.S., Eds.; Sage Publications: Thousand Oaks, CA, USA, 1993; pp. 136-162.

115. Si, H.; Shi, J.; Tang, D.; Wu, G.; Lan, J. Understanding intention and behavior toward sustainable usage of bike sharing by extending the theory of planned behavior. Resour. Conserv. Recycl. 2020, 152, 104513. [CrossRef]

116. Chen, A.; Peng, N. Recommending green hotels to travel agencies' customers. Ann. Tour. Res. 2014, 48, 284-289. [CrossRef]

117. Liu, P.; Teng, M.; Han, C. How does environmental knowledge translate into pro-environmental behaviors?: The mediating role of environmental attitudes and behavioral intentions. Sci. Total Environ. 2020, 728, 138126. [CrossRef]

118. Irianto, H. Consumers' attitude and intention towards organic food purchase: An extension of theory of planned behavior in gender perspective. Int. J. Manag. Econ. Soc. Sci. 2015, 4, 17-31.

119. Buabeng-Andoh, C. Predicting students' intention to adopt mobile learning: A combination of theory of reasoned action and technology acceptance model. J. Res. Innov. Teach. Learn. 2018, 15, 124-143. [CrossRef]

120. Zheng, G.-W.; Siddik, A.B.; Masukujjaman, M.; Alam, S.S.; Akter, A. Perceived Environmental Responsibilities and Green Buying Behavior: The Mediating Effect of Attitude. Sustainability 2021, 13, 35. [CrossRef] 